\title{
Younger Middle Terrace - Saalian pre-Drenthe deposits overlying MIS 7 Nachtigall interglacial strata near Höxter/ Weser, NW-Germany
}

\author{
Peter Rohde, Jochen Lepper, Wolfgang Thiem †
}

How to cite:

Abstract:

Kurzfassung:

Keywords:
Rohde, P., Lepper, J., Thiem, W. † (2012): Younger Middle Terrace: Saalian pre-Drenthe deposits overlying MIS 7 Nachtigall interglacial strata near Höxter/Weser, NW-Germany. - E\&G Quaternary Science Journal, 61 (2): 133-145. DOI: 10.3285/eg.61.2.02

\begin{abstract}
Subrosion of Lower Triassic evaporites by subsidence has preserved peat coal and clay as Pleistocene warm and cool stage deposits near Höxter in the northwest-German uplands. There, in the upper reaches of the River Weser, peat coal and clay are sandwiched by gravel and sand of two river terraces; they were exploited in a small pit called Grube Nachtigall. Exploration drillings from 1997/98 enabled investigating a $13.5 \mathrm{~m}$ core with the warm and cool stage deposits in respect of sedimentology, palynostratigraphy and radiometric dating. In 2011 the results concerning this "Nachtigall-Complex" have been published separately by two groups of authors also concerned with the project. Since 1994 also analyzing lithostratigraphy and structure of the Pleistocene framework, that is to say about 25 square kilometers of valley floor and hillside landscape, has been the aim of the methodologically independent study presented here. The subrosion structure turned out to be partly limited by faults. The most important Pleistocene mapping units are the deposits of 4 river terraces; in descending chronological order these are: - youngest Upper Terrace, not dislocated - Older Middle Terrace, subsided - Younger Middle Terrace, not subsided - Lower Terrace, not subsided, its sediments partially lying upon subsided Older Middle Terrace deposits. The layers of Nachtigall-Complex likewise directly overlie subsided Older Middle Terrace deposits and with an angular unconformity are overlain by Younger Middle Terrace deposits; they are subsided and deformed. According to generally accepted traditional mapping outside the study site, the Older Middle Terrace has to be assigned to the MIS 8 equivalent in the lower part of the Saalian Complex, and the Younger Middle Terrace to the deep MIS 6 equivalent in the deepest portion of the upper Saalian Complex, i.e. pre-Drenthe. Hence the palynological as well as the radiometric MIS 7 age of the recently defined Nachtigall 1 Interglacial correspond to the lithostratigraphic model inferred from structural analysis.
\end{abstract}

Die vor-drenthe-zeitliche Jüngere Mittelterrasse über dem MIS 7 Nachtigall-Interglazial - Elemente der Subrosionsstruktur Albaxen bei Höxter/Weser, NW-Deutschland

In einer Subrosionsstruktur über Evaporiten des Oberen Buntsandstein sind im Bergland am Oberlauf der Weser zwischen Höxter und Holzminden pleistozäne warm- und kühlzeitliche „Tone“- und „Torfe“ erhalten geblieben. Sie trennen hier kaltzeitliche Terrassen-Kiese und -Sande der Weser. Als Rohstoff wurden sie in dem kleinen Tagebau Nachtigall abgebaut. Aus Bohrungen, die 1997/98 zur Erkundung der Lagerstätte u.a. als Rammkernbohrungen niedergebracht wurden, standen für geowissenschaftliche Untersuchungen $33 \mathrm{~m}$ nahezu durchgehende Kernstrecke zur Verfügung. Daraus konnten 13,5 m für sedimentologische, palynostratigraphische und radiochronologische Untersuchungen ausgewählt werden. Diese warm- und kühlklimatischen Ablagerungen wurden als Nachtigall-Complex zusammengefasst und 2011 von zwei Autorengruppen des Projekts in zwei methodisch unterschiedlichen Artikeln veröffentlicht. Als geologischer Rahmen wurden $25 \mathrm{~km}^{2}$ Flussniederungs- und Hanglandschaft seit 1994 lithostratigraphisch und strukturgeologisch mit dem hier vorgelegten Ergebnis analysiert. Die zuvor schon bekannte Subrosionsstruktur erwies sich als z.T. von Störungen begrenzt. Die wichtigsten pleistozänen Kartiereinheiten sind die Sedimentkörper von 4 Flussterrassen; nach abnehmendem Alter sind dies: - jüngste der Oberterrassen, nicht abgesunken - Ältere Mittelterrasse (ÄMT), abgesunken - Jüngere Mittelterrasse, nicht abgesunken - Niederterrasse, z.T. auf Schichten der abgesunkenen ÄMT. Die Schichten des Nachtigall-Complex liegen direkt über Schichten der ÄMT und werden von Schichten der Jüngeren Mittelterrasse diskordant überlagert; sie sind abgesunken und verformt. Außerhalb des Untersuchungsgebietes wird die ÄMT - ihrer Lage in der Terrassentreppe gemäß - dem Marinen Isotopen-Stadium MIS 8 im unteren Teil des Saale-Komplex zugeordnet, die Jüngere Mittelterrasse dem älteren Abschnitt von MIS 6 im tiefen oberen Teil des Saale-Komplex vor dem Drenthe-Stadium. Damit wird das sowohl palynostratigraphisch als auch radiometrisch ermittelte MIS 7-Alter des zwischen beiden liegenden jüngst definierten Nachtigall 1 Interglazial lithostratigraphisch gestützt.

Younger Middle Terrace, Wehrden-Niveau, Nachtigall 1 Interglacial, Older Middle Terrace, Reiherbach-Niveau, Saalian Complex, pre-Drenthe period, MIS 6, MIS 7, MIS 8, mapping, lithostratigraphy, structural analysis, river terrace, staircase-position, stackposition, Weser upper reaches, Albaxen subrosion structure, NW-Germany

Addresses of authors: P. Rohde, Müdener Weg 61, 30625 Hannover, Germany; J. Lepper, Ahldener Straße 10 E, 30625 Hannover, Germany; both formerly state geological survey of Lower Saxony, today's Landesamt für Bergbau, Energie und Geologie, Hannover 


\section{Introduction}

If we look back to the starting point of the present study in 1998, we find:

- a pit for exploiting peat coal and clay for manifestly more than a century -

- ice age deposits of interglacial character taken note of for at least a hundred years -

- questionable assignment of the warm period strata to the Pleistocene stratigraphy -

We also find a drilling project for expanding the area of open cast working to the north. Jochen Lepper located and supervised the drillings, evaluated the drilling project (LEPPER 1998, 2011) and made available core KB 1 for scientific investigation. He also coordinated the studies that are based on structural analysis plus lithostratigraphy, on sedimentology, on palynology plus palynostratigraphy, and on radiometric dating. An initially envisaged common publication regrettably has not been realized as it turned out to be too complex and too long. Special mention should be made of the comprehensive palaeobotanic analyses of Helmut Müller, by which he unravelled intricate depositional environments of peat coal and clay. Thus he determined the stratigraphic position of Nachtigall-Complex, got aware of its contemporaneity with the succession of Göttingen / Ottostraße (GRÜGER 1996), and found out the analogy with the Velay profile, Massif Central, south-central France (REILLE et al. 2000, BEAulieu et al. 2001). His death called for finally supporting his palynostratigraphic conclusions. The way in which the authors accounted for the bio- and chronostratigraphic results has been outlined by KLEINMANN, MÜLlER, LEPPER \& WAAS (2011).

Peter Rohde could discuss thoroughly his results of terrace stratigraphy and his ideas concerning the source of certain fine-grained clastic matter with Helmut Müller. His terrace model is supported by results of the deceased field geoscientist and highly appreciated colleague Wolfgang Thiem, Hannover University, Geographic Institute (THIEM 1988; RoHDE \& THIEм 1998). Wolfgang Thiem has taken active part in the field work in Nachtigall pit. The present paper has been initiated by Jochen Lepper, who above all contributed the geological setting.

We would like to point to the end of text where abbreviations are explained.

\section{Study site}

The study area in the Weser Valley in NW-Germany is situated in the Mesozoic uplands, about $60 \mathrm{~km}$ south of their northern edge. Here, downstream of the medieval town of Höxter, about 25 square kilometers of valley floor and hillside landscape are included (Fig. 1). For orienting oneself, a more prominent place may be Corvey Abbey near Höxter, a world heritage name because of the 1130 years old, well preserved Carolingian westwork.

The so called Zeche NACHTIGALL (Nightingale pit) is at a place that since the middle of the 16th century is called "Bergstette“ in terms of a prospective site (MichaEL КосH, Höxter, personal communication 2010). It has been exploited maybe since 1795 ( $\Rightarrow$ Tonenburg - in Wikipedia [27 Fe- br.2012]), maybe from the 1840s (Schlegel 1997). Documentarily mentioned, subsurface peat-coal mining was practiced at least since 1857 (SCHLEGEL 1997: map of mine 1866) up to a date well before 1884/86 (CARTHAUs 1886), and about 1920 until 1923. Besides, "clay" has been extracted temporarily by open cast work having started some time between 1866 and 1884. In 1895 the Feldbrandziegelei Johann Buch was founded. Recently the brickworks Ziegelwerk Buch at Höxter-Albaxen, in its small Nachtigall clay pit (Fig. 1, 2, 3) extracted minor quantities of peat coal, but primarily carbonaceous pelites as before.

It is worth noting that at a distance of about $150 \mathrm{~km}$, at Witten-Bommern, Ruhr district, there is another ancient pit with the same name Zeche Nachtigall. 1743-1892, this former colliery produced carboniferous hard coal, and 2003 has been transformed into the identically named Industrial Museum.

\section{Previous research}

The peat and clay deposits of Nachtigall pit have attracted interest since the 19th century (DECHEN 1884; CARTHAus 1886; KoKEN 1901; SIEGERT 1913, 1921; SOERGEL 1927, 1939; STOLLER 1928). In 1908/09 and 1927 first thorough studies were conducted to present the geological map $1: 25000$, sheet Holzminden, today's number 4122 (GRUPE 1912, 1929). Much later the site-specific extraordinary Pleistocene succession in the south of the mapped area was dealt with again (BRELIE et al. 1971, MüLLER 1986, Rohde 1989, Rohde \& THIEM 1998). MANGElSDORF (1981) studied geologically the Nachtigall site and investigated palynologically the succession of its Middle-Pleistocene organic deposits. The hydrogeological aspect of the area has been investigated by STRAATEN (1982) and Fischer et al. (1990). The latest information was given by an unpublished report by LEPPER (1998) in the context of the company's request to the authorities for extending the hitherto granted exploitation of the carbonaceous brick clay. For archived supporting documents see LEPPER (2011).

\section{Borehole evidence}

The present structural study and map are based on boreholes of very different informative value (Fig. 2,3) that may be divided into 5 groups.

1) Three percussive core / wash boreholes as exploration boreholes for exploring the extension of the clay and peat deposit, additionally used as groundwater observation-wells / Grundwassermeßstellen (LEPPER 1998, 2011).

KB 1 (1998), cored 10-43 m; the core was investigated sedimentologically and palynologically in great detail (KLEINMANn et al. 2011), partially also by radiometric dating (WAAs, KLEINMANN \& LEPPER 2011);

Gauss-Krueger grid reference R 3527755 / H 5741 810, elevation $+108.55 \mathrm{~m} \mathrm{NN}$; geographic coordinates $51^{\circ} 48^{\prime} 34.8^{\prime \prime} \mathrm{N} / 9^{\circ} 24^{\prime} 04.7^{\prime \prime} \mathrm{E}$.

KB 2 (1998), cored 10-13 m / 15-16 m / 18.2-32 m, washed for the rest; Gauss-Krueger grid reference R 3527855 / H 5741 805, elevation +105.27 m NN. 


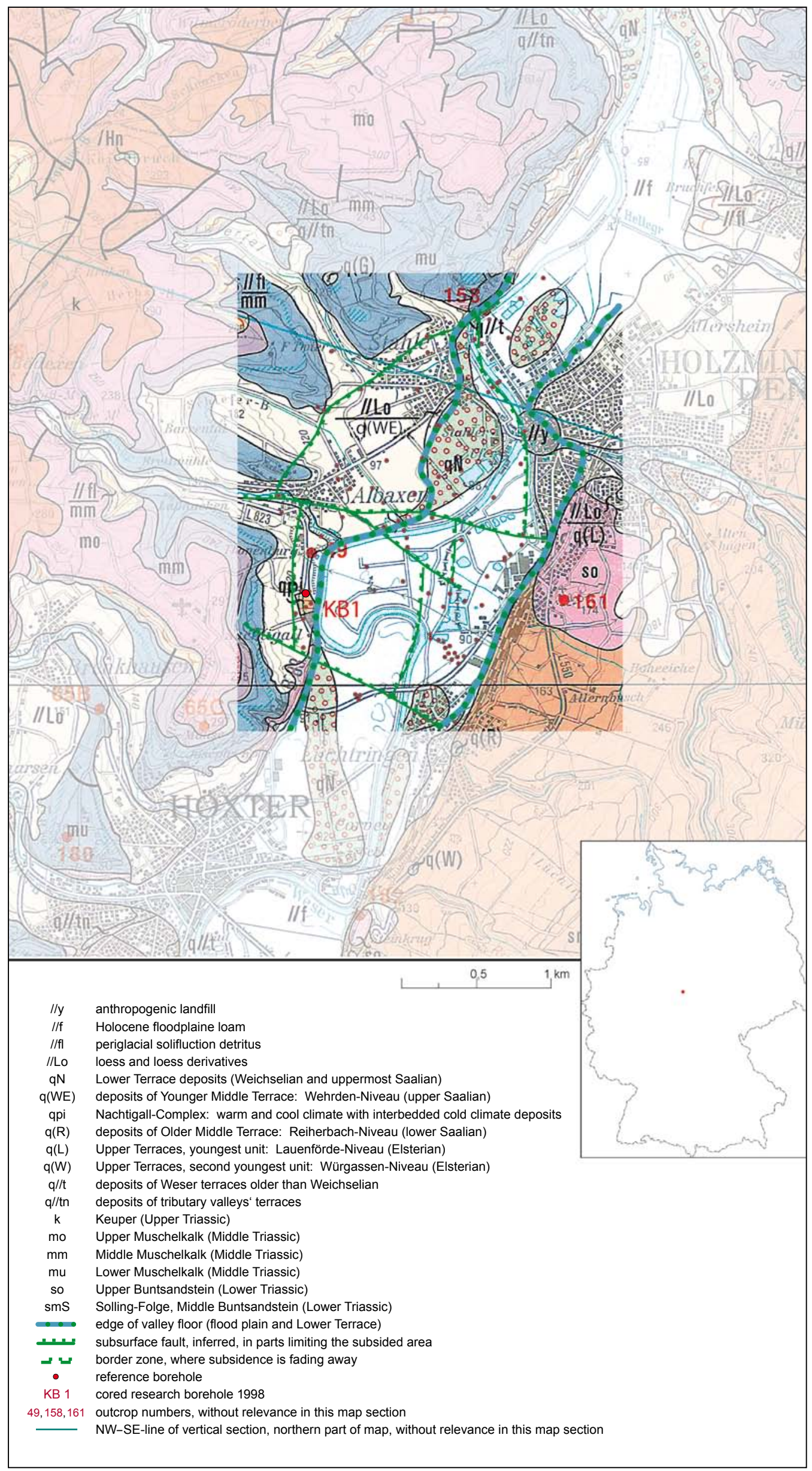

Fig. 1: Geological Setting. Taken from LEPPER \& MENGELING (1990), with modifications. As to further details see Fig. 2. Abb. 1: Geologischer Rahmen. Nach LEPPER \& MENGELING (1990), mit Änderungen. Weitere Signaturen siehe Abb. 2. 
KB 3 (1998), partly cored 15-17 m, cored 17-28 m depth, washed for the rest; Gauss-Krueger grid reference R 3527888 / H 5741 665, elevation +102.22 m NN.

2) Three additional wash boreholes as exploratory and groundwater observation wells; these are B 1, B 2, B 4 (1998) of $36 \mathrm{~m} / 27.5 \mathrm{~m} / 31 \mathrm{~m}$, having penetrated the clay and peat deposit (LEPPER 1998).

3) Eight percussion boreholes S 1 - S 8 (1997), up to $13 \mathrm{~m}$ deep, for groundwater observation and for investigating the strata that overlie the clay and peat deposit (LEPPER 1998).

4) Approximately 50 boreholes for gravel-exploration and groundwater survey in the surroundings of the clay and peat deposit (1952 and 1972-1998, data bases of the state geological surveys Landesamt für Bergbau, Energie und Geologie, Hannover, as well as Geologischer Dienst Nordrhein-Westfalen, Krefeld).

5) According to GRUPE (1929) five historical exploration boreholes in the context of coal mining activities, $54 \mathrm{~m}$ (about 1905) and $18 \mathrm{~m} / 20 \mathrm{~m} / 28 \mathrm{~m} / 29 \mathrm{~m}$ (about 1919).

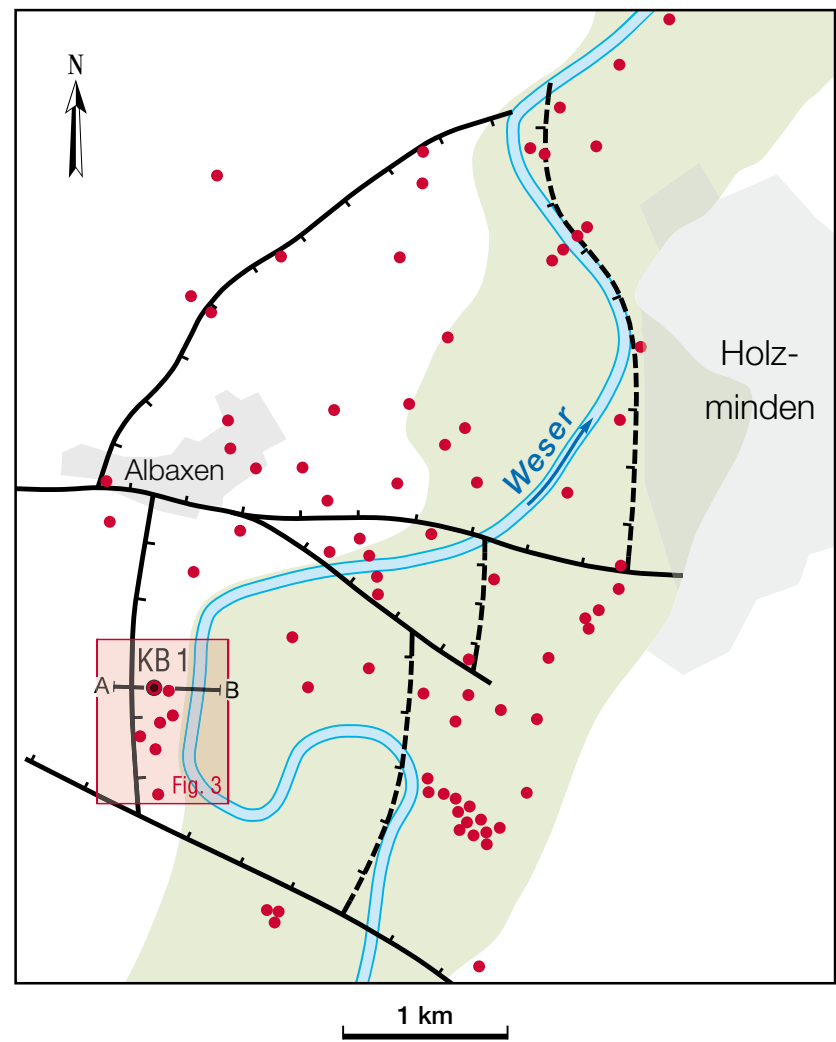

valley floor (flood plain and Lower Terrace)

subsurface fault, inferred, in parts limiting the subsided area

--- border zone, where subsidence is fading away

- reference borehole

Fig. 2: Albaxen subrosion structure. Central part of Fig. 1, augmented. Mapping 2008 by Peter Rohde.

Abb. 2: Subrosionsstruktur von Albaxen. Innerer Teil von Abb. 1, vergrößert. Kartierung 2008, Peter Rohde.

\section{Methods}

The geological study is principally concerned with the structural analysis of a $25 \mathrm{~km}^{2}$ area around Nachtigall pit with its deposits of interglacial character (Nachtigall-Succession, KLEINMANN et al. 2011). It distinguishes lithostratigraphic units and decodes the intricate structure of their horizontal and vertical relative positions. Finally it aims at assigning the elements of the structural geological model to Pleistocene stratigraphy (LiTT et al. 2007) and to the chronostratigraphically calibrated MIS system of Marine ${ }^{16} \mathrm{O}$-Isotope Stages (e.g. PetiT et al. 2000).

The lithostratigraphic and the structural investigations comprise geological mapping in the pit and applying the detailed geological map 1:25000 by GrUPE (1929) and also the diploma thesis by STRAATEN (1982). Moreover it comprises evaluating historical mine plans as well as evaluating, interpreting and correlating the petrographic borehole data of all sorts of borehole records available (see above). Ground level elevation refers to German Ordnance datum NN (Normal Null) mainly according to Topographic Map 1:5 000, partly to Topographic Map 1:25000.

Assigning the sedimentary bodies to specific units of the Pleistocene stratigraphy has been carried out on the base of
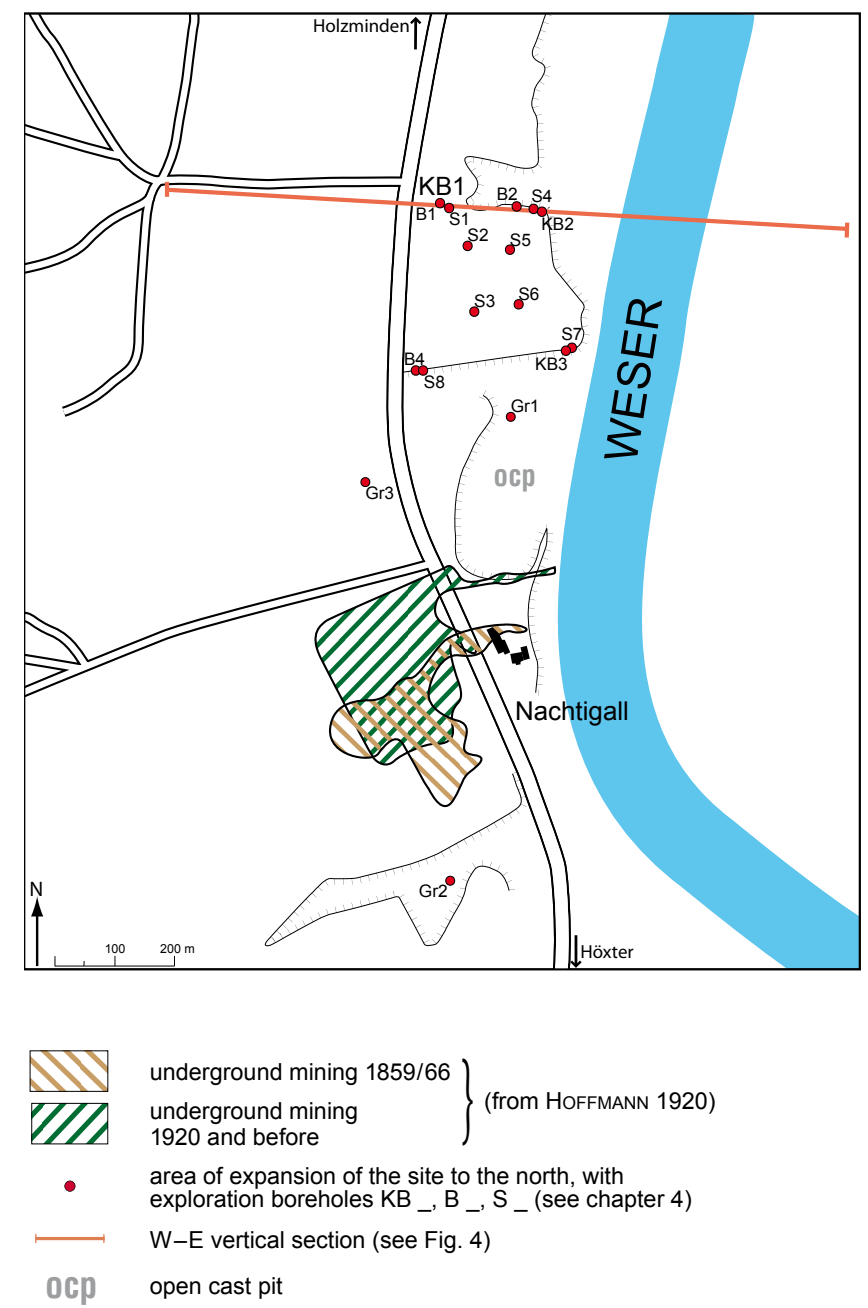

Fig. 3: Plan of Nachtigall pit. Topography from Deutsche Grundkarte 1 : 5 000, Nachtigall, 3526 Rechts, 5740 Hoch.

Abb. 3: Geländegrundriss der Grube Nachtigall. Topographie nach Deutsche Grundkarte $1: 5$ 000, Nachtigall, 3526 Rechts, 5740 Hoch. 
Table 1: Quaternary lithostratigraphic units in Albaxen site near Höxter, NW-Germany. The site includes the Albaxen subrosion structure with the warm, cool, and cold stage sedimentsts of Nachtigall-Deposit. Data concerne base level, surface level and thickness of lithostratigraphic units (RoHDE 2008). Maximum subsidence suggested 62-65 $\mathrm{m}($ ? $78 \mathrm{~m})$.

Tabelle 1: Quartärzeitliche lithostratigraphische Einheiten im Gebiet Albaxen bei Höxter in NW-Deutschland. Das Gebiet umfasst die Subrosionsstruktur von Albaxen mit den warm-, kühl- und kaltzeitlichen Nachtigall-Lagerstättenschichten. Erfasst sind die Einheiten nach Basis- und Oberflächen-Höhenlage und Mächtigkeit (RоHDE 2008). Die Absenkung durch Subrosion beträgt maximal vermutlich 62-65 $\mathrm{m}$ (? $78 \mathrm{~m}$ ).

\begin{tabular}{|c|c|c|c|c|c|c|}
\hline deposits & $\begin{array}{l}\text { base: mete } \\
\text { NN }\end{array}$ & 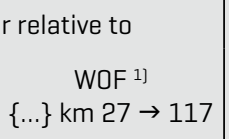 & $\begin{array}{l}\text { recent surface } \\
\text { meter NN }\end{array}$ & recent & thickness: & $\begin{array}{l}\text { meter } \\
\text { maximum }\end{array}$ \\
\hline $\begin{array}{l}\text { Upper Terraces, } \\
\text { Lauenförde Niveau }\end{array}$ & $116 \rightarrow 126$ & $\{28 \rightarrow 37\}$ & 132 [?] & & & \\
\hline $\begin{array}{l}\text { Older Middle Terrace [Reiherbach Niveau] } \\
\text { ditto: subsided } \\
\text { - borehole KB } 3 \text { / } 1998 \\
\text { - borehole KB } 2 \text { / } 1998 \\
\text { - borehole GRUPE } 1 \text { [1919?] } \\
\text { OMT, subsided and undistinguishably cov- } \\
\text { ered by Lower Terrace } \\
\text { OMT, subsided, base extremely low-lying }\end{array}$ & $\begin{aligned} & 103 \rightarrow 110 \\
&<74.2 \\
&<73.3 \\
&<69.9 \\
& 71.0 \rightarrow 75.5 \\
& 40.8 / 38.0 / ? 25.1\end{aligned}$ & $\begin{array}{l}\{15 \rightarrow 22\} \\
\quad<-13.6 \\
\quad<-14.4 \\
\quad<-18\end{array}$ & & $11.4[n=8]$ & 8.0 & $\begin{array}{l}4 \\
: 5 \\
=7.3 \\
\end{array}$ \\
\hline $\begin{array}{l}\text { Nachtigall-Deposit, subsided } \\
\text { ditto: top low-lying due to erosion }\end{array}$ & $72.5 \rightarrow 82.4$ & & $\begin{array}{l}94.2 \rightarrow 99.0 \\
87.1 \rightarrow 89.1\end{array}$ & $19.2[n=3]$ & $\begin{array}{r}13.3 \\
6.7\end{array}$ & $\begin{array}{r}25.0 \\
8.7\end{array}$ \\
\hline $\begin{array}{l}\text { Younger Middle Terrace [Wehrden Niveau] } \\
\text { - borehole KB } 2 \text { / } 1998 \\
\text { - borehole B } 2 \text { / } 1998 \\
\text { - borehole KB } 3 \text { / } 1998\end{array}$ & $\begin{array}{l}87.07 \\
87.56 \\
89.12\end{array}$ & $\begin{array}{l}\{-4 \rightarrow-1\} \\
-0.7 \\
-0.1 \\
+1.4\end{array}$ & $\begin{array}{l}94.7 \\
95.3 \\
92.2\end{array}$ & \} $6.0[n=3]$ & \{ & $\begin{array}{l}7.4 \\
7.7 \\
2.8\end{array}$ \\
\hline $\begin{array}{l}\text { solifluction matter incl. "loess" } \\
\text { "loess": [sandy] loess, partly reworked }\end{array}$ & $92.2 \rightarrow 99.0$ & & $\begin{array}{l}\text { ground level } \\
\text { exceeding that of } \\
\text { Lower Terrace }\end{array}$ & $\begin{array}{r}10.4[n=10] \\
2.5[n=12]\end{array}$ & $\begin{array}{l}9.0 \\
2.0\end{array}$ & $\begin{array}{r}11.0 \\
3.1\end{array}$ \\
\hline $\begin{array}{l}\text { Lower Terrace } \\
\text { ditto: top low-lying due to erosion and } \\
\text { covered with floodplain loam }\end{array}$ & $76.2 \rightarrow 80.3$ & $\begin{array}{c}\{-11 \rightarrow-6\} \\
\text { са }-9\end{array}$ & $\begin{array}{l}86.2 \rightarrow 88.5 \\
84.5 \rightarrow 87.0\end{array}$ & $\begin{array}{c}\text { ca } 9 \\
7.6[n=33]\end{array}$ & 5.0 & 10.2 \\
\hline floodplain loam [Holocene] & $84.5 \rightarrow 87.0$ & & {$[88.5 ? \rightarrow] 86.2[84.8]$} & $2.6[n=40]$ & 0.6 & 3.5 \\
\hline \multicolumn{3}{|c|}{$\begin{array}{l}\text { 1] WOF: Water-level of over-bank flooding; corresponding to Mittleres Hochwasser } \\
\text { MHW [ Mean annual highest water-level] 1941-1980, Weser-km 73-83 }\end{array}$} & $88.5 \rightarrow 84.8$ & & & \\
\hline
\end{tabular}

mapping experience both in the uplands of Lower Saxony with their fluvial terraces (e.g. RoHDE 1989) and in the lowlands with their drift sediments and, moreover, in the borderland in between. For broad understanding the present article refers to the MIS-system (Marine isotope stages) as has been taken into account by LiTT et al. (2007).

\section{Geological setting: the solid rock}

The Nachtigall clay pit is situated at the western flank of the anticlinal structure "Solling-Gewölbe" built up by red beds of the Buntsandstein group (Germanic Lower Triassic) that comprises a clastic, pelitic sequence with evaporitic interbeds in its upper portion (Fig. 1). Only $0.7 \mathrm{~km}$ west of Nachtigall pit shallow marine sediments of the Muschelkalk group (Germanic Middle Triassic) that overlays the Buntsandstein group are outcropping. The bottom of the Buntsandstein is built up by an Upper Permian (Zechstein) succession of marine evaporites and carbonates underlain by Lower Permian (Rotliegend) red beds which rest unconformably on the folded Variscan basement.
After updoming of the Mesozoic sediment pile in the course of late Cretaceous to Tertiary times, the antecedent River Weser subsequently incised an isoclinal valley from late Tertiary to late Pleistocene in the zone between the western flank of the Buntsandstein-anticline and the outcropping Lower Muschelkalk to the west of it. In the study area the Weser valley generally follows the strike of the Upper Buntsandstein beds with pelites and evaporites easily to be eroded.

Within the Upper Buntsandstein mudstone and evaporites, leaching processes have affected chloride and sulfate layers. The process started in the evaporite outcrop area at the western flank of the "Solling-Gewölbe" and successively prograded from east to west and from surface to subsurface according to the regional dip. The original evaporite thickness might have been up to approximately $100 \mathrm{~m}$.

Therefore in the western part of the present valley and on the adjacent hillside this general geological setting is complicated by a subrosion structure as a sediment-,trap“ of Pleistocene age which cannot be recognized morphologically at the ground surface but which is reflected by the "trapped“ 


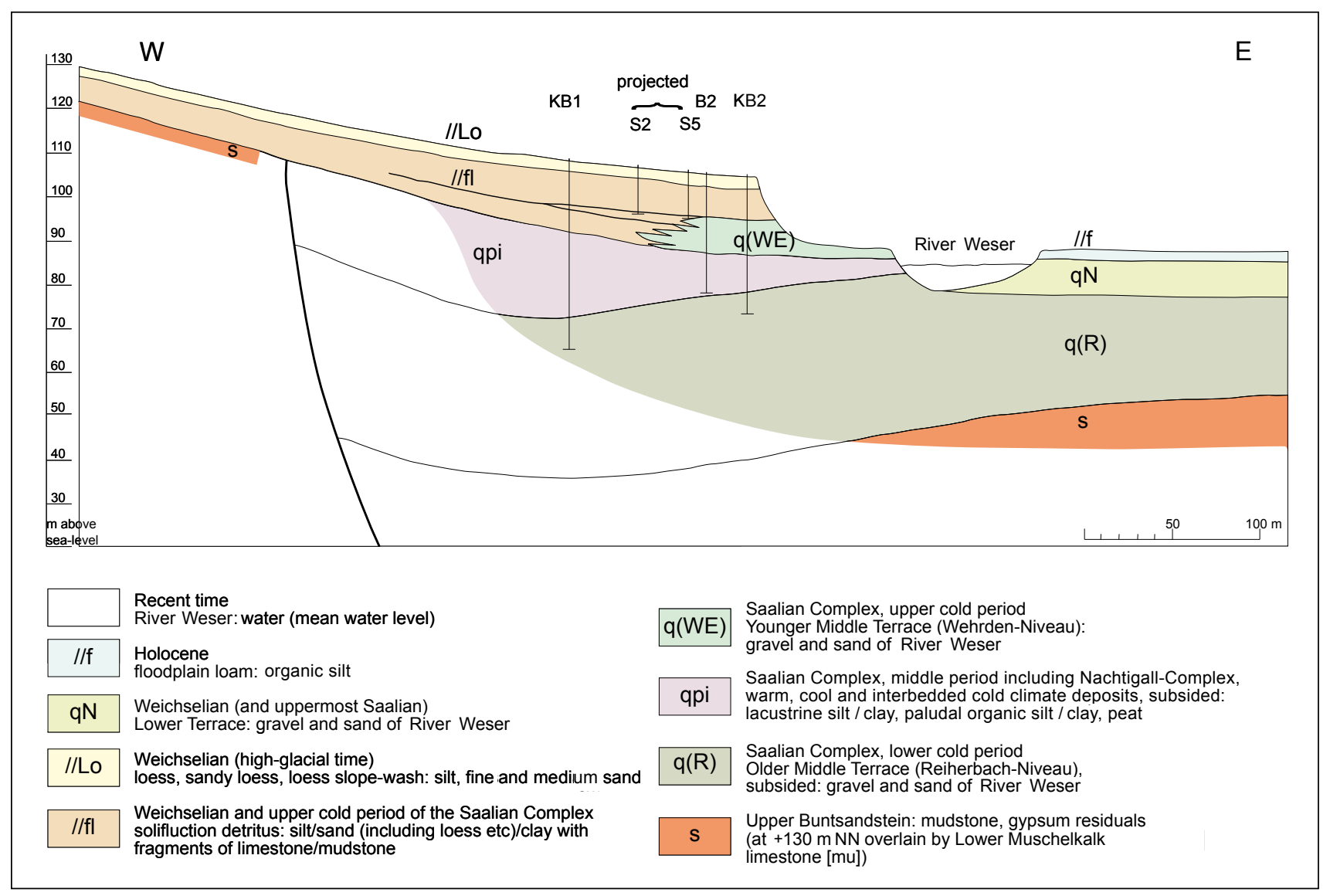

Fig. 4: MIS 7 Nachtigall interglacial deposits between Saalian Older Middle Terrace and Younger Middle Terrace of the River Weser in stack-position (!not: staircase-position). Cross section; main focus upon Nachtigall concession near Albaxen, $N$ of Höxter, NW-Germany. Draft: Peter Rohde in 2008. As to the up-to-date stratification of KB 1 borehole profile see KLEINMANN et al. (2011) and present paper, section 7.2.

Abb.4: Ablagerungen des MI-Stadium 7 mit Nachtigall-Interglazial. Vorkommen zwischen der Älteren und der füngeren Weser-Mittelterrasse aus der Saale-Kaltzeit in Stapel-Lagerung (und nicht Treppen-Lagerung). Vertikaler Querschnitt, im Wesentlichen durch das Gelände der Konzession Nachtigall bei Albaxen nördlich von Höxter in NW-Deutschland. Entwurf: Peter Rohde i.f. 2008. Zur aktuellen Gliederung der Schichtenfolge in Bohrung KB 1 siehe KLEINMANN et al. (2011) sowie Abschnitt 7.2 der vorliegenden Veröffentlichung.

sediments („Albaxen subrosion structure“, Fig. 1 and 2) and is dealt with in chapter 7 .

\section{The Quaternary deposits within and adjacent to the subsided area}

The fossil subrosion structure is $5 \mathrm{~km}$ by 2 or 3 respectively, the long axis following the SSW-NNE trending Weser valley (Fig. 1 and Fig. 2; RoHde 2008). The Pleistocene depositional environment comprises two different sedimentary complexes belonging to different morphological units.

\subsection{Today's valley floor}

This flat ground extends as far as the mainly Weichselian Lower Terrace and the Holocene flood plain (Fig. 1). The surface level of the Lower Terrace is at +86.2 to $+88.5 \mathrm{~m} \mathrm{NN}$, whereas that of the flood plain only is at $86.2 \mathrm{~m}$ on average (84.8-88.5 m; Table 1). The top layers of the Lower Terrace comprise $2 \mathrm{~m}$, in some parts $3 \mathrm{~m}$ of sandy loess-like loam, deposited by a periglacial river in the braided river plain during a period of very low river activity. Yet in the flood plain there have been accumulated $2.5 \mathrm{~m}$ (min: $0.5 \mathrm{~m}$, max: $3.5 \mathrm{~m}$ ) of organic sandy or argillaceous silt, deposited as over-bank sediments during floods of the meandering
Weser. Beneath both of them there are periglacial braided river sand and gravel of the Lower Terrace with a supposed base level of +76.2 to $+80.3 \mathrm{~m} \mathrm{NN}$, that is $9 \mathrm{~m}$ below recent Water-level of over-bank flooding (WOF), on average.

In a certain area similar sand and gravel are also found below this level (Fig. 2; Fig. 4: $q(\mathrm{R})$ ), in eight boreholes down to $+71 \mathrm{~m} \mathrm{NN}$, and in a few boreholes still deeper, with a minimum value of +40.8 and possibly even $+25.1 \mathrm{~m} \mathrm{NN}$. The resulting overall thickness of sand and gravel is $11.5 \mathrm{~m}$ on average and $46 \mathrm{~m}$ as maximum in comparison with $7.5 \mathrm{~m}$ concerning the Lower Terrace separately. This difference of thickness is explained by subsidence due to subrosion, the lower part of the sediment stack interpreted as Older Middle Terrace sediments (see below); the actual situation suggests deposition of only that series during subsidence of the bedrock beneath it.

\subsection{Today's hillside}

The subrosion structure is not confined to the valley floor, but westward also comprises the lower part of the hillside downhill the Muschelkalk escarpment and also includes the Nachtigall open cast pit. The surface of the slope is built up by loess and solifluction detritus (gelifluction detritus) of limestone and mudstone with thin slopewash intercala- 


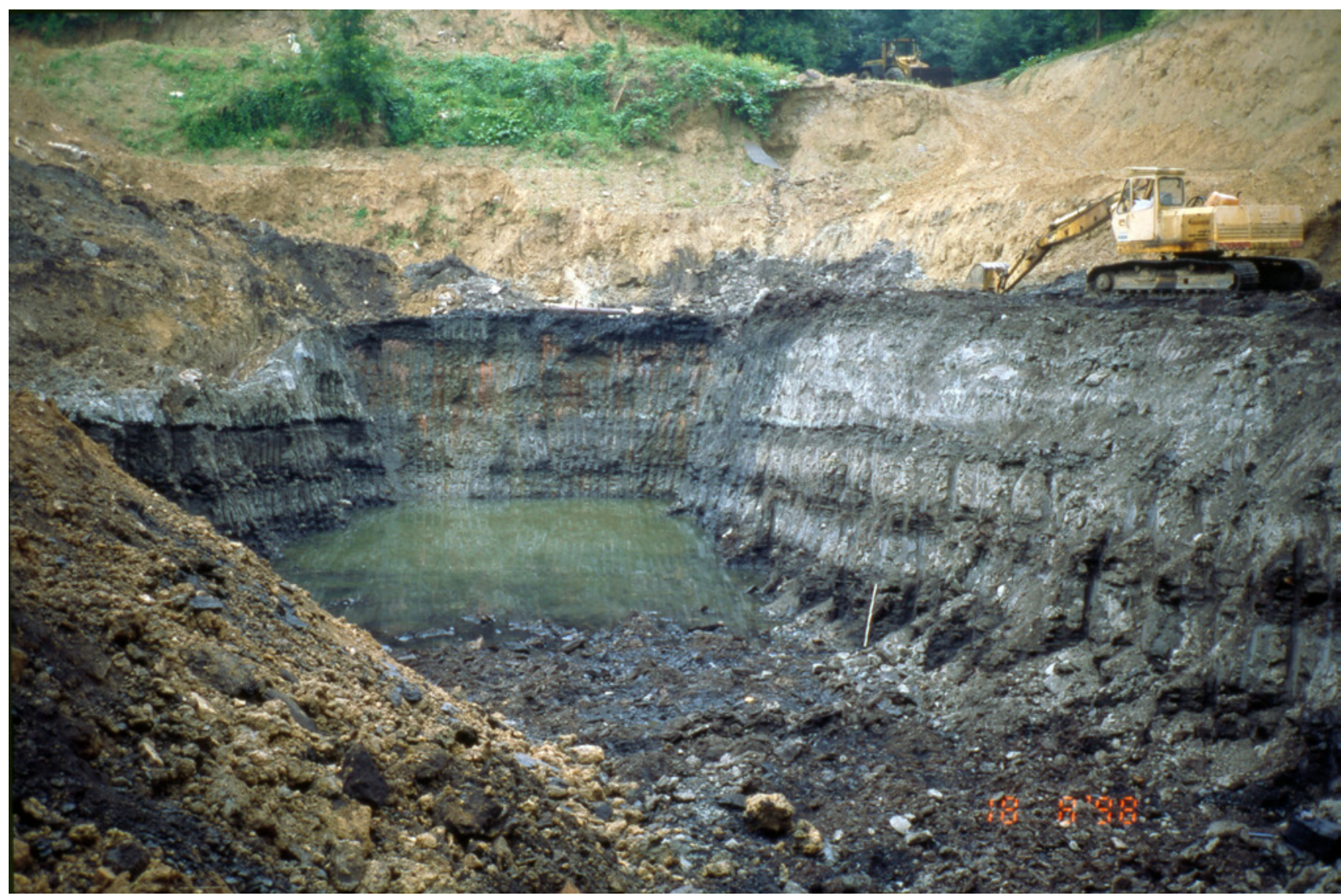

Fig. 5: Temporary outcrop of Nachtigall 1 Interglacial with peats A, B, C and D. As to lithostratigraphy see chapter 9. Folding ruler $1 \mathrm{~m}$. Photo fochen Lepper, 18 August 1998. Approximate thicknesses are: - peat (D) $1.40 \mathrm{~m}$, upper part not visible, - clay and silt $1.90 \mathrm{~m}$, - peat (C) $0.05 \mathrm{~m}$, - clay and silt $1.00 \mathrm{~m}$, - peat (B) $0.40 \mathrm{~m}$, - clay and silt (lower part dark) $0.85 \mathrm{~m}$, - peat (A) $1.30 \mathrm{~m}$, lower part not visible.

Abb. 5: Kurzzeitiger Aufschluss des Nachtigall 1 Interglazial mit den Torfen A, B, C und D. Zur Lithostratigraphie siehe Kapitel 9. Messstab 1 m. Foto fochen Lepper, 18.8.1998. Die Mächtigkeit der Schichten beträgt etwa: - Torf (D) 1,40 m, oberer Teil nicht sichtbar, - Ton und Schluff 1,90 m, - Torf (C) 0,05 m, - Ton und Schluff 1,00 m, - Torf (B) 0,40 m, - Ton und Schluff (unterer Teil dunkel) 0,85 m, - Torf (A) 1,30 m, unterer Teil nicht sichtbar.

tions of red, originally eolian sand. These periglacial sediments in the northern pit area are 9-11 m thick (Fig. 4, Table 1) and include an Eemian palaeosol of decalcification. They are down-dipping towards the adjacent valley floor in the east. In the open cast pit they overlie their substratum at an angular unconformity, as the substratum got troughshaped by subrosion, and in its eastern part was tilted to the west and eroded at its former surface.

Concerning the substratum up to $25 \mathrm{~m}$ of lacustrine silt, clay and mud are interbedded with several seams of slightly calciferous peat. In the recent quarry all these sediments (Fig. 5) are dipping in westerly directions towards the slope; the bedding would assign the investigated section to the eastern flank of a very shallow syncline if compared with the former subsurface mining area farther in the south. The interglacial, interstadial and included stadial layers, in borehole KB 1 core comprising $10 \mathrm{~m}$ of sediments, by A. Kleinmann have been termed Nachtigall-Succession (KLeinmann et al. 2011; see Chapter 9). The whole $13.5 \mathrm{~m}$ section studied palynologically in KB 1 core by A. Kleinmann has been termed Nachtigall-Complex; it encloses $3.5 \mathrm{~m}$ of cold and cool climate lacustrine mud and fen peat in its upper part. - With additional cold climate lacustrine $(7.22 \mathrm{~m})$ and ambiguous lacustrine or slope sediments $(4.28 \mathrm{~m})$ the KB 1 core section is called Nachtigall-Deposit in the present paper (Table 1).
In summary the terms used for sections of KB 1 core and in the present paper are

Nachtigall-Succession: contains the deposits of interglacial / interstadial character (36.00-26.02 m); Nachtigall-Complex: strata with arboreal pollen $>20 \%$, i.e. at least „tree tundra" (36.00-22.50 m); Nachtigall-Deposit: contains peat and clay in terms of natural mineral resource (36.00-11.00 m).

Within the Nachtigall-Succession and its lowest section, i.e. Nachtigall 1 Interglacial, the base of Allochthonous Unit I (cf. Chapter 9) includes dropstones of Weser characteristics without nordic material (pebbles 2-20 cm, sample K.D. Meyer, August 1998, analysis P. Rohde \& J. Lepper, December 1998). Similarly the base of Allochthonous Unit II includes an erratic boulder of Swedish Dala quartzite (GRUPE 1929: "Bohrung 4", meaning a shaft, but localisation regrettably not to be verified). It must have been transported primarily by the Elsterian inland ice, then might have been deposited in Thuringia and ice drifted from there on a lake or by the river. Alternatively it might have been drifted directly from the north to Nachtigall site on an Elsterian ice dammed lake (e.g. WINSEMANN et al. 2011; see also Chapter 10) and perhaps furthermore slid down at the slope above the pit area from an unknown Elsterian secondary deposit. The extraordinary lateral supply of mineral matter in warm climate periods still is worth discussing (see Chapter 10).

Adjacent to the present valley floor, the Nachtigall-Depos- 


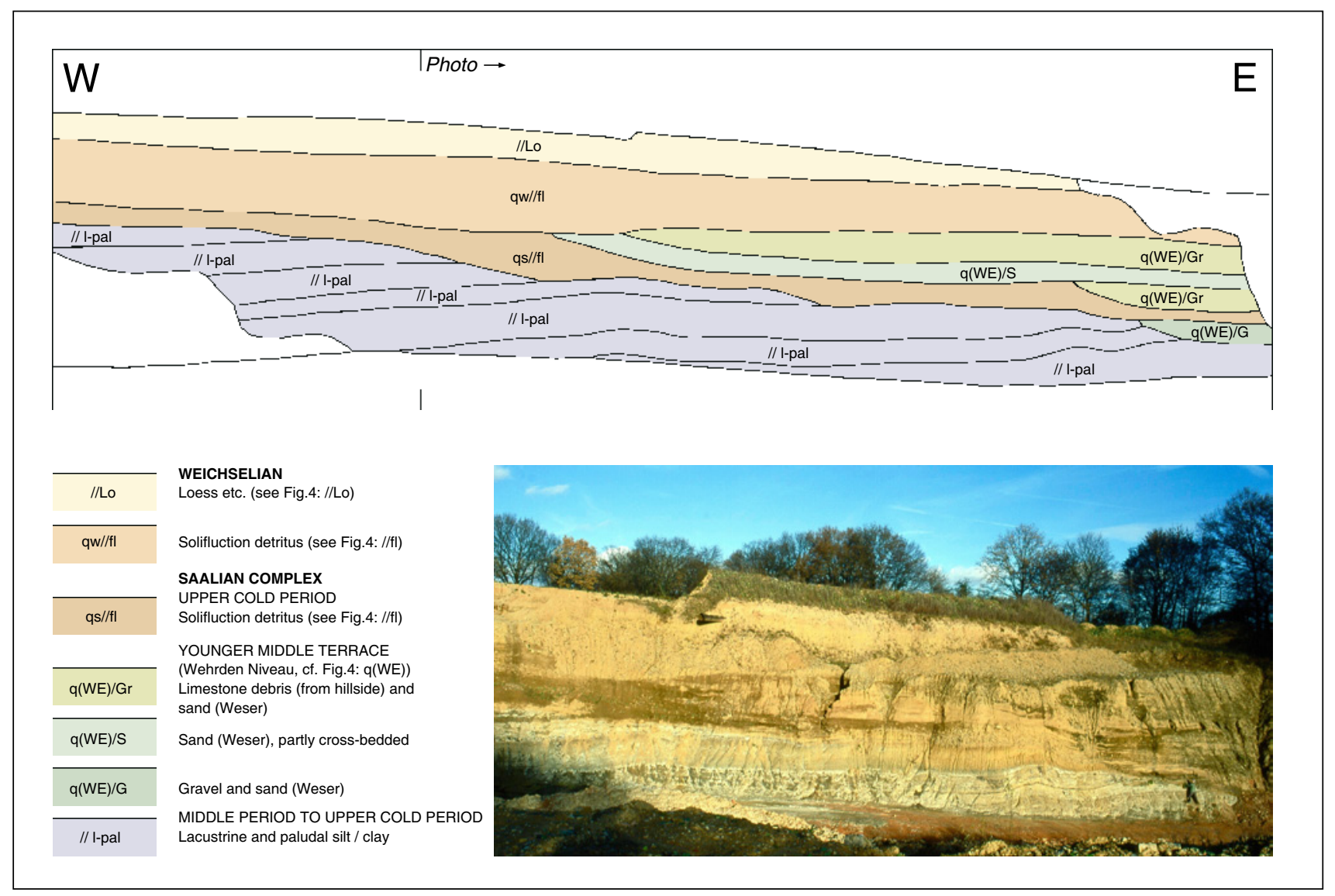

Fig. 6: Younger Middle Terrace deposits interfingering with solifluction detritus. Quarry face, autumn 2011. Drawing: - left margin $R 35$ 27 760, H 5741 690, elevation +108.7 m NN, height above bottom 16.4 m, - right margin R 3527 875, H 5741 685, elevation +103.5 m NN, - width 115 m. Photo: - left margin R 3527 790, H 5741 700, elevation +107.3m NN, - width 85 m. Above numerical data approximate only. Folding rule in middle of photo: $1 \mathrm{~m}$; at right margin: $2 \mathrm{~m}$. Photos fochen Lepper, 7 Oct. and 30 Nov. 2011. Photo interpretation Peter Rohde. For the first time the quarry face exposes the complete overburden stack of the Nachtigall-Deposit in a W-E section, appr. hundred meters south of section AB (Fig. 3, Fig. 4).

Abb.6: Ablagerungen der Jüngeren Mittelterrasse, verzahnt mit Solifluktionsschutt. Grubenwand, Herbst 2011. Zeichnung: - linker Rand R 35 27 760, H 5741 690, Gelände +108,7 m NN, Wandhöhe 16,4 m, - rechter Rand R 3527 875, H 5741 685, Gelände +103,5 m NN, - Wandlänge 115 m.

Foto: - linker Rand R 3527 790, H 5741 700, Gelände +107,3 m NN, - Wandlänge 85 m. Alle Lage-Angaben als Circa-Werte. Messstab im Foto, Mitte: 1 m; rechter Rand: $2 \mathrm{~m}$. Fotos fochen Lepper, 7.10. und 30.11.2011. Foto-Auswertung Peter Rohde. Erstmals erschließt die Grubenwand die vollständige Schichtenfolge über der Nachtigall-Lagerstätte in einem W-E-Schnitt etwa 100 m südlich des Schnitts AB (Abb. 3, Abb. 4).

it partially was eroded at the top. Forming an angular unconformity, the erosion surface partially has been covered by up to $8 \mathrm{~m}$ - or perhaps more - of fluvial gravel and sand attributed to the younger Saalian Weser terrace (Younger Middle Terrace or Wehrden-Niveau, Table 1, Fig. 4, Fig. 5; RoHDE 1989). The strata have not been dislocated, their base level is at +87 to $+89 \mathrm{~m} \mathrm{NN}$ (GRUPE 1929: geol. Map), i.e. minus $0.7 \mathrm{~m}$ to plus $1.4 \mathrm{~m}$ relative to WOF. These dates are in accordance with results of a reference survey (ROHDE 1989). Partially the sediments interfinger with the solifluction detritus mentioned above. Later, the fluvial gravel and sand were covered with different periglacial sediments, which also capped the western, less or not eroded part of the Nachtigall-Deposit.

In KB 1 borehole above the Nachtigall-Deposit no fluvial, but only sediments of the slope were encountered (Fig. 4). In contrast KB 2 core drilling revealed Younger Middle Terrace sediments top-down consisting of:

$1.9 \mathrm{~m}$ medium-grained sand with silt, fine sand, coarse sand, little fine grit, red brown, fluvial (Weser)

$5.7 \mathrm{~m}$ gravel, with sand and coarse pebbles, red to grey, fluvial (Weser).
This succession is typical for a fluvial sediment series formed during periglacial conditions.

The Nachtigall-Deposit is underlain by fluvial gravel and sand assigned to the older Saalian Weser terrace (Older Middle Terrace or Reiherbach-Niveau, Table 1; RoHDE 1989). By the pit-extension drillings its base was not reached, lying deeper than $+74 \mathrm{~m}$ to $+70 \mathrm{~m} \mathrm{NN}$. In the valley-floor where this gravel and sand are also found their base might be at about $+41 \mathrm{~m} \mathrm{NN}$ minimum (or even +25 m NN, see above).

\subsection{Basin structure and development}

The two morphological elements, that means valley floor and hillside (section 7.1, section 7.2), are divided by a young scarp at the foot of the hillside (Fig. 4: $10 \mathrm{~m}$ east of KB 2 borehole) and close to it by an escarpment visible as steep western river bank and extending down below the river surface (Fig. 4: $80 \mathrm{~m}$ east of KB 2). Both faces are due to fluvial downcutting. The latter, being the older one, originated when the Lower Terrace river formed the deep incision and the wide periglacial braided river plain at the end of the 
Saalian period. The former resulted from partial erosion of the Lower Terrace sediment stack near to its former surface at late-glacial time.

Yet the overall structure is complex. Information from outcrops, boreholes and from the geological map especially of the pit area suggest that subsidence by subrosion affected only the Older Middle Terrace and the Nachtigall-Deposit. Faults (Fig. 1, Fig. 2) are supposed to have been effective as slides during subsidence. At least partially they may have been caused by subrosion. Only the aforementioned sediments were dislocated. There are neither indications of subsidence concerning Elsterian deposits (Table 1; RoHDE 1989: Lauenförde Niveau; Grupe 1929: geol. Map: Obere Terrasse between $+120 \mathrm{~m}$ and $+132 \mathrm{~m} \mathrm{NN}$ ) nor are there indications concerning the sediments of Younger Middle Terrace and of Lower Terrace and of the periglacial slope deposits. In the valley floor, larger differences of thickness of Pleistocene deposits beneath the Holocene flood plain also must be explained by subsidence. There, this process exclusively has affected the Older Middle Terrace sediments underlying the Lower Terrace sediments in great parts. Towards the east, beneath floodplain loam and Lower Terrace gravel and sand, the preservation of Older Middle Terrace deposits by subrosion is fading away. It is important to note that Older Middle Terrace sediments subsided by subrosion have been identified at several sites of the Weser valley, so near Polle, Bodenwerder and maybe also near Hameln (Thiem, Fleig, Kliem partly joint in Rohde \& Thiem 1998: 116, 120, 141; besides orally by W. Thiem).

As to maximum subsidence there is no validated evidence. From three dates of Older Middle Terrace sediments a subsidence of ca $65 \mathrm{~m}$, perhaps even of ca $78 \mathrm{~m}$, relating to their undisturbed base level in an upper Weser reference survey by RoHDE (1989) are worth being considered.

Generally the base of the Quaternary deposits seems to be irregular as a result of different degrees of subrosion. There might exist various sinking centers within the basin. Tracing a contour map of the base of the Quaternary sediments in a coherent manner regrettably remains left till additional boreholes provide less scattered and less discontinuous data distribution.

\subsection{Postscript findings in autumn 2011}

The advance of the open cast work to the north of the pit area made possible studying the complete overburden stack of the Nachtigall-Deposit in a vertical and straight quarry face for the first time. The study corroborates principally the borehole data evaluation as presented in the cross section of Fig. 4. Beyond that, explicitly examined it reveals the onlapping superposition of younger units on deformed and hill-ward dipping clay/silt layers of Nachtigall-Deposit. On an erosive basal face the onlapping units comprise horizontal Younger Middle Terrace gravel and sand in the east as well as the lowest solifluction unit in the west. Most instructive to see how the younger fluvial sediments are directly supplied by limestone debris, that have been transported downslope by periglacial solifluction. The overlying fluvial red sand displays evidently that the periglacial fluvial activity weakened in the final stages as generally is known from the latest phase of terrace build- ing accumulation, e.g. concerning Lower Terrace top layers (Rohde \& Becker-Platen 1998: 42; 2002: 106). Fig. 6 summarizes our supplementary findings. It displays the quarry face in direction of the hill slope and across the strike of the clay deposits, as exposed in autumn 2011. It refers to section 2 of chapter 7 and supports evidently the suggested synthesis. The drawing is based on reconnaissance examination in the pit, supplemented by a relevant photo evaluation.

At the time mentioned the brickworks being in liquidation, the outcrop is in risk to get lost, unfortunately.

\section{Discussion: Younger Middle Terrace}

The Younger Middle Terrace seems to be a weakly developed geologic and hardly to distinguish morphologic element. It might be overlooked therefore in most cases. Its base in staircase position is minus $4 \mathrm{~m}$ (to minus $1 \mathrm{~m}$ ) relative to WOF mapped by a reference survey (RoHDE 1989). That implies only ca $5 \mathrm{~m}$ of difference to the base of the Lower Terrace and a position lower than the Lower Terrace surface. Like the sediment package of the Older Middle Terrace it is one of the geological units that build up the slope along the side of a recent valley. Consequently its surface lying at the bottom of a slope is hidden by slope deposits and / or loess. Possibly in upland positions Younger Middle Terrace deposits with a rather low surface level escape the geologist's notice at the edge of the Lower Terrace or are visible only in outcrops.

Thus field mapping is in risk not to discern the deposits where both terraces really are existing and then simply defines a mapping unit ,Middle Terrace ${ }^{6}$ in the sense of the common Older Middle Terrace, the more so as this is supposed to be the main Saalian fluvial formation in Lower Saxony (yet WANSA in LITT et al. 2007: 38). If the sediments of different terraces occur as stack, as is the case due to subrosion (W. Thiem concerning Weser valley: THIEM 1988; RoHDE \& THIEM 1998) and generally is the case in lowland regions, they might be complete, but inevitably are difficult to identify in case they lack interbedded interglacial deposits.

\section{Conclusion: MIS 8 -, MIS 7 - and prior to Saalian inland glaciation MIS 6 -deposits}

The fluvial deposits of the two Middle Terraces have to be assigned stratigraphically to pre-Drenthe-stadial periods of the Saalian Complex (LitT \& Turner 1993, LitT et al. 2007). In and around Nachtigall pit the deposits match the stratigraphic units as tabulated below (Tab. 2).

The direct contact of the sediments which in Tab. 2 are accentuated by heavy print, contrasts with common terrace staircases in uplands; this fact must be emphasized sufficiently. In their special position demonstrated in Fig. 4, the two terraces corroborate that the Nachtigall-Succession with its interglacial and stadial layers has been deposited during Marine Isotope Stage 7 (MIS 7) and neither during the Holsteinian (MIS 9e, GEYH \& MüLLER 2005) nor during the Eemian (MIS 5e) interglacial periods. The correlation of the Holsteinian interglacial alternatively to MIS 11 cannot be discussed here.

As has been mentioned the fluvial activity leading to the 
Table 2: Deposits of Nachtigall site matched to the stratigraphic scheme for North Germany. Loess and solifluction deposits (Weichselian, Warthe and period of Younger Middle Terrace) omitted.

Wehrden Niveau, Reiherbach Niveau: according to ROHDE 1989.

Bouchet 2, Bouchet 3: according to BEAULIEU et al. 2001 and others (see chapter 9).

N. Nachtigall

$\Downarrow$ deposits subsided by subrosion.

Tabelle 2: Schichteinheiten im Gebiet der Grube Nachtigall im stratigraphisches Schema für Nord-Deutschland.

Löss und Solifluktionsablagerungen (Weichsel-Kaltzeit und Warthe-Stadium und Zeit der Jüngeren Mittelterrasse) nicht einbezogen.

Wehrden-Niveau, Reiherbach-Niveau: nach RоHDE (1989).

Bouchet 2, Bouchet 3: nach BEAULIEU et al. 2001 und weiteren (s. Kap. 9).

N. Nachtigall

$\Downarrow$ Ablagerung durch Subrosion abgesenkt.

\begin{tabular}{|c|c|c|c|c|c|}
\hline \multicolumn{4}{|c|}{$\begin{array}{l}\text { NORTH GERMANY } \\
\text { LITT et al. 2007, with regard to ongoing discussion } \\
\text { modified according to proposal of KLEINMANN et al. } 2011\end{array}$} & \multicolumn{2}{|c|}{ NACHTIGALL SITE } \\
\hline Weichselian & MIS 2-5d & \multicolumn{2}{|c|}{ cold period with interstadials } & \multicolumn{2}{|l|}{ Lower Terrace } \\
\hline Eemian & MIS 5e & \multicolumn{2}{|l|}{ Interglacial } & \multicolumn{2}{|c|}{ [decalcification on slope] } \\
\hline \multirow[t]{10}{*}{ Saalian Complex } & \multirow{4}{*}{ MIS 6} & \multirow{2}{*}{$\begin{array}{l}\text { Warthe- + } \\
\text { Drenthe- } \\
\text { Stadium }\end{array}$} & & \multicolumn{2}{|c|}{ [? Lower Terrace, older part] } \\
\hline & & & [glaciation] & & \\
\hline & & \multicolumn{2}{|c|}{$\begin{array}{l}\text { cold stage } \\
\text { [?Delitzsch-Phase] }\end{array}$} & \multicolumn{2}{|c|}{$\begin{array}{l}\text { Younger Middle Terrace } \\
\text { [Wehrden Niveau] }\end{array}$} \\
\hline & & & with interstadials & \multicolumn{2}{|c|}{$\begin{array}{l}\text { Stadial of N.-Deposit } \Downarrow \\
\text { Stadials }+5 \text { Interstadials of } \\
\text { N.-Complex / -Deposit } \Downarrow\end{array}$} \\
\hline & MIS 7a & \multicolumn{2}{|c|}{$\begin{array}{l}\text { warm stage [cf. Velay, } \\
\text { France: Bouchet 3] }\end{array}$} & \multirow{3}{*}{$\begin{array}{l}\text { Nachtigall- } \\
\text { Succession } \Downarrow \\
\text { [i.e. lower part of } \\
\text { N.-Complex / } \\
\text { lowest part of } \\
\text { N.-Deposit] }\end{array}$} & $\begin{array}{l}\text { N.2 Inter- } \\
\text { stadial }\end{array}$ \\
\hline & MIS 7b & \multicolumn{2}{|l|}{ cool stage } & & $\begin{array}{l}\text { Albaxen } \\
\text { Stadial }\end{array}$ \\
\hline & MIS 7c & \multicolumn{2}{|c|}{$\begin{array}{l}\text { Interglacial [cf. Velay, } \\
\text { France: Bouchet 2] }\end{array}$} & & $\frac{\text { N.1 Inter- }}{\text { glacial }}$ \\
\hline & MIS 7d, e & \multicolumn{2}{|c|}{ [cool stage, warm stage] } & & \\
\hline & MIS 8 & \multicolumn{2}{|l|}{ cold stage } & \multicolumn{2}{|c|}{$\begin{array}{l}\text { Older Middle Terrace } \\
\text { [Reiherbach Niveau] } \Downarrow\end{array}$} \\
\hline & MIS 9a-d & \multicolumn{2}{|c|}{ [2 warm, 2 cool stages] } & & \\
\hline Holsteinian & MIS 9e & \multicolumn{2}{|c|}{ [Interglacial] } & & \\
\hline \multirow[t]{3}{*}{ Elsterian } & \multirow[t]{3}{*}{ MIS 10} & \multirow[t]{3}{*}{ cold period } & & & \\
\hline & & & [glaciation] & & \\
\hline & & & & \multicolumn{2}{|c|}{ youngest Upper Terrace } \\
\hline
\end{tabular}

accumulation of the Younger Middle Terrace occurred before the Drenthe-stadial ice had covered northern Germany. For the time in question temperature and dust records from Antarctica suggest a span between ca 190 (200) and 160 ka b.p. (temperature-against-time-graph of Vostok ice core, see Petit et al. 1999, Petit et al. 2000).

On the basis of palynological and sedimentological studies in $\mathrm{KB} 1$ core, A. Kleinmann distinguished the following units (KLEINMANN et al. 2011):

Nachtigall 1 Interglacial, 36.0-28.60 m, corresponding to Bouchet 2 in the Velay sequence (BeAulieu et al. 2001, ReILle et al. 2000, Tzedakis et al. 1997) and to MIS 7c. The warm period sediments consist of peat, clay and mud with intercalated layers of allochthonous material:

peat A 36.00-34.70 (GruPE 1929: Unterflöz des Haupttorflagers)

Allochthonous Unit (I) 34.70-33.85

peat B and lacustrine clay / mud 33.85-33.25 (GRUPE 1929: Oberflöz des Haupttorflagers)

Allochthonous Unit (II) 33.25-30.00, with peat C at $32.00-31.97 \mathrm{~m}$

peat D 30.00-28.60. 
Albaxen Stadial, 28.60-27.05 m, corresponding to Bonnefond in the Velay sequence and to MIS $7 \mathrm{~b}$.

Nachtigall 2 Interstadial, 27.05-26.02 m, corresponding to Bouchet 3 in the Velay sequence and to MIS 7a. At 27.0026.54 it contains dark clay (organogenic layer E).

Stadials $1-5,26.02-22.50 \mathrm{~m}$, separated by the minor Interstadials 1-4, corresponding to Costaros in the Velay sequence and to the beginning of MIS 6.

Dating of core samples from KB 1 borehole by TIMS ${ }^{230} \mathrm{Th} / \mathrm{U}$ method yielded the following isochron corrected ages (WAas, KleinMann \& LePPer 2010):

$227+9$ / -8 ka for birch fen peat sample 34.87-34.83 m (closed system within peat $\mathrm{A}$ )

$201+15$ / -13 ka for brown moss peat sample 33.63-33.47 m (closed system within peat B)

$206 \pm 6 \mathrm{ka}$ for fen peat sample 28.90-28.82 m (closed system within peat $\mathrm{D})$.

An attempt at dating the clay sample 26.8-26.7 $\mathrm{m}$ with ca $15 \%$ organic matter (organogenic layer E) yielded an age $177 \pm 8$ ka which seems to be not consistent with the palynological results, a higher age being expected.

As a result of these contemporary research activities by three-way approach, the warm climate deposits of Nachtigall pit, known since a long time, actually have to be assigned to MIS 7 warm stage periods. The present study contributes lithostratigraphic aspects: directly subjacent as well as directly overlying gravel deposits represent Older Middle Terrace and Younger Middle Terrace respectively and thus also establish the age of the Nachtigall warm climate deposits as mid-Saalian MIS 7.

\section{Further tasks}

Allochthonous Unit I as well as Allochthonous Unit II of Nachtigall-Complex (Chapter 7.2, Chapter 9) have equivalents in the succession of Göttingen-Geismar, Ottostraße, $50 \mathrm{~km}$ away from Nachtigall pit (GRÜGER et al. 1994; KLEINMANN et al. 2011, mentioning this correlation as orally communicated by Helmut Müller in or just before 2007). The respective sections with their striking amounts of mineral matter from the slope occur at the same palynostratigraphic positions during warm climate. Catastrophic rainfalls during the periods in question might have torn open the plant cover at slopes and thus made possible the anomalous mass transport (KLEINMANN et al. 2011). Apparently the events on which the contemporaneity is based were not triggered by seismic activities: there is no evidence of earthquakes in sedimentological record, and in fact the palynological record even revealed certain vegetational developments in Allochthonous Unit I and Allochthonous Unit II (A. Kleinmann, orally). A conclusive explanation of the circumstances that determined the contemporaneity of the peculiar sedimentation at both sites seems to be worth further study.

By their climatic conditions of accumulation the Nachtigall warm and cool climate deposits are expected to yield archaeological finds that have not been taken into account so far.

As to lithostratigraphy it is an open question, how the inland ice influenced sedimentation at the study site from its margin about $20 \mathrm{~km}$ in the north. We have to assume that ice dammed lakes covered the upper valley of the River Weser (glacial Lake Weserbergland, WORTMANN 1998; glacial Lake Weser, WinsEMANN et al. 2009, 2011). The surface of the Drenthe valley floor might have been at a level of about $+95 \mathrm{~m} \mathrm{NN}$ at the least, being formed by the Younger Middle Terrace. Up to now glaciolacustrine finegrained sediments or delta or subaqueous fan deposits have not been identified in or around Nachtigall pit. - According to GRUPE (1929) an erratic boulder of Swedish Dala quartzite was found in the pit area, beneath $0.5 \mathrm{~m}$ of Weser gravel and $17.4 \mathrm{~m}$ of "clay" with some peat layers at a depth of $23.9 \mathrm{~m}$. Yet it was interbedded in allochthonous deposits of Nachtigall 1 Interglacial and not in glacial sediments (cf. Chapter 7.2).

A fundamental stratigraphic detail is concerning the base of the Lower Terrace deposits. This means the question whether the Weser as a braided river formed the deep incision and the wide periglacial valley plain by downcutting really during the deglaciation at the end of the Saalian Complex. Subsequently still prior to the Eemian interglacial the Lower Terrace aggradation started during cold and wet climate and continued after the interglacial. This model applies accordingly to older terraces (WORTMANN 1968, WORTMANN \& Wortmann 1987, BRIDGland 1994, Schreve 2004, McNABB 2007). On closer inspection the very important process of downcutting already may have been initiated as fluvial response to sea level lowering prior to the advance of the inland ice. This model may be inferred from Elsterian fluvial and fluvioglacial deposits („Flußrinnen-Schichten“) in the former Weser valley in and near Hannover (RoHDE 1983, 1994, ROHDE \& BECKER-PLATEN 1998: 38f., 138f., 34f.).

\section{In Memoriam}

This work has been accomplished in reverence for Helmut Müller (20 July 1924 - 18 June 2008) who opened the palaeobotanical secrets of the Nachtigall deposits and stratigraphically assigned them to a still incompletely known mid-Saalian warm stage.

\section{Acknowledgements}

Mr. Robert Buch generously granted the permission to publish the geoscientific data from exploration boreholes of the Buch brickworks company at Höxter-Albaxen and from our studies in the pit. Angelika Kleinmann and Deniz Waas agreed to take the sedimentological and radiometric part of the project; Mrs. Kleinmann also agreed to continue the palynological work of Helmut Müller. From among our Hannoverean colleagues Klaus-Dieter Meyer contributed to some extent to the field work and Mebus A. Geyh, just as Jutta Winsemann, Hannover, visited the pit. Each of them, likewise Eberhard Grüger, Göttingen, and our colleague Josef Merkt were readily critical dialogue partners. - Jochen Farrenschon, Krefeld, cooperatively assisted us in communicating with the state geological survey 
Geologischer Dienst Nordrhein-Westfalen. - Stephan Dreher and Guntram Herrendorf provided assistance in electronic data processing. - Hansjörg Streif contributed comprehensive and detailed advice to improve the manuscript, and Julia Knowles proofread the English text as a native speaker. Finally two reviewers gave helpfully constructive comments. To all of them we express our gratitude.

\section{Abbreviations}

ka b.p. Kilo annos (thousand years) before present (1950)

MIS Marine isotope stage (warm or cold stage of Quaternary period, established by temperature-dependent ${ }^{18} \mathrm{O} /{ }^{16} \mathrm{O}$ oxygen isotopes ratio of marine calcareous microfossil shells [foraminifers] or glacier ice). Alternative notation: MI stage. In general odd numbers are applied for warmer stages, even numbers for colder stages

NN German Ordnance datum (Landkarten-Bezugshöhe Normal Null)

OMT Older Middle Terrace (older Saalian fluvial terrace)

TIMS Thermal ionisation mass spectrometry

WOF Water-level of over-bank flooding. Correspondingly: level of younger alluvial clay (Jüngerer Auelehm). Also correspondingly: 30/40 years mean annual highest water-level (Mittleres Hochwasser MHW 1941-70/80)

\section{References}

Beaulieu, J.-L. De, Andrieu-Ponel, V., Reille, M., Grüger, E., Tzedakis, C. \& Svobodova, H. (2001): An attempt at correlation between the Velay pollen sequence and the Middle Pleistocene stratigraphy from central Europe. - Quaternary Science Reviews, 20: 1593-1602.

Brelie, G.v.D., Nowak, H., Preising, E. \& Rohde, P. (1971): Quartär zwischen Holzminden und Hehlen. - Arbeitsgemeinschaft Nordwestdeutscher Geologen, 38. Tagung Holzminden 1971, Führer [guide] Exkurs. 4.6.1971: 19 p., 2 + 1 fig., 4 tab.; Hannover.

BRIDGLAND, D.R. (1994): Quaternary of the Thames. - XIII + 441 p.; London (Chapman \& Hall).

Carthaus, E. (1886): Mitteilungen über die Triasformation im nordöstlichen Westfalen und in einigen angränzenten Gebieten. - Philosophische Dissertation: 69 p.; Würzburg (Druck und Verlag der Stahel'sche Universitäts-Buch- und -Kunsthandlung).

Dechen, H. von (1884): Erläuterung zur geologischen Karte der Rhein provinz und der Provinz Westfalen. - Vol. 2, A: 933 p.; Bonn (Henry).

Fischer, U., Gàl, A. \& Michel, G. (1990): Die Subrosionssenke von Albaxen bei Höxter und ihre Bedeutung für die Wassergewinnung. - Neues Jahrbuch für Geologie und Paläontologie, Abhandlungen, 181 / 1-3: 531-547.

Geyh, M.A. \& MüLLER, H. (2005): Numerical 230Th/U dating and a palynological review of the Holsteinian/Hoxnian Interglacial. - Quaternary Science Reviews, 24:1861-1872.

GrÜGER, E. (1996): Palynostratigraphy of the middle Pleistocene sequence from Göttingen, Otto-Strasse. - In: Turner, C. (ed.): The Early Middle Pleistocene in Europe: 173-180; Rotterdam (A.A. Balkema).

Grüger, E., Jordan, H., MeIschner, D., Schlie, P. (1994): Mittelpleistozäne Warmzeiten in Göttingen, Bohrungen Ottostrasse und Akazienweg. Geologisches Jahrbuch A 134, 167-210, 8 fig., 4 tab., 1 pl..

Grupe, O. (1912 / 1929): Geologische Karte von Preußen $1: 25$ 000, mit Erläuterungen [explanatory notes], sheet 4122 Holzminden. - 1st / 2nd edit., 71 p., 1 pl., 1 map ; Berlin.

HoffMANN [surveyor of mines] (1920): Braunkohlenrube Nachtigall, Grubenriss $1: 1000$, Amtliches Grubenbild [map of mine]. - Ziegelwerk Buch, Höxter-Albaxen. - [unpubl., archives of company].

Hoffmann [surveyor of mines] (1922): Braunkohlenrube Nachtigall, Profil A-B, $1: 750$ and $1: 750 / 200$, Amtliches Grubenbild. - Ziegelwerk Buch, Höxter-Albaxen. - [unpubl., archives of company].
Kleinmann, A., Müller, H., Lepper, J. \& WaAs, D. (2011): Nachtigall: A continental sediment and pollen sequence of the Saalian Complex in NGermany and its relationship to the MIS-framework. - Quaternary International 241 (2011): 97-110, 5 fig.. DOI: 10.1016/j.quaint.2010.10.005.

KoKen, E. (1901): Beiträge zur Kenntnis des schwäbischen Diluviums. - Neues Jahrbuch für Mineralogie, Geologie und Paläontologie, 14: $120-170$.

LEPPER, J. (1998): Geologisch-lagerstättenkundliches Gutachten zur geplanten Erweiterung der Tongrube Nachtigall in Höxter-Albaxen (Reg.-Bez. Detmold). - 5 p., 9 append.; Hannover. - [unpubl. - Landesamt für Bergbau, Energie und Geologie, archives: 0119544].

LePper, J. (2011): Tongrube Nachtigall bei Albaxen (Landkreis Höxter). Arbeitsunterlagen [documentation] 1996-2011. - Drill and outcrop records, photos, plans, 1 map, 1 lithological gravel analysis, etc.; Hannover. - [unpubl. - Landesamt für Bergbau, Energie und Geologie, archives: 0130075].

Lepper, J. \& Mengeling, H. (1990): Geologische Wanderkarte Mittleres Leinebergland mit Naturpark Solling-Vogler, $1: 100$ 000, mit Beiheft [map with explanatory notes]. - Beiheft Bericht Naturhistorische Gesellschaft Hannover: 58 p., 1 map; Hannover.

Litt, T., Behre, K.-E., Meyer, K.-D., Stephan, H.-J. \& Wansa, S. (2007): Stratigraphische Begriffe für das Quartär des norddeutschen Vereisungsgebietes. - Eiszeitalter und Gegenwart, 56 (1-2): 7-65.

LitT, T. \& Turner, C. (1993): Arbeitsergebnisse der Subkommission für Europäische Quartärstratigraphie: Die Saalesequenz in der Typusregion (Bericht der SEQS 10). - Eiszeitalter und Gegenwart, 43: 125-128; Deutsche Quartärvereinigung.

McNabi, J. (2007): The British Lower Palaeolithic. - 420 p.; London (Routledge).

MANGELSDORF, P. (1981): Quartärgeologische und paläobotanische Untersuchungen in der Tongrube „Nachtigall“ N Höxter/Weser. - Dipl.-Arbeit Geol. Inst. Univ. Hannover: 63 p., 12 fig., 6 tab., 4 pl.; Hannover. - [unpubl. - Landesamt für Bergbau, Energie und Geologie, library: 1986 B 404].

MüLlER, H. (1986): Interglazial der Grube Nachtigall bei Albaxen: cf. „Bilshausen e“ und „““? - In: P. Rohde (1986), Geo-Umwelt im Bergland-Quartär zwischen oberer Weser und Leine. - Deutsche Quartärvereinigung DEUQUA, 23. Tagung, Celle, Führer [guide] Exkurs. B: 19 p.; Hannover.

NowAK, H. (1971): Torf und Ton unter Mittelterrassen-Kies, Tongrube (Zeche) Nachtigall, Albaxem südlich Holzminden. - In: G. V.D. BRELIE et al. (1971), Quartär zwischen Holzminden und Hehlen. Arbeitsgemeinschaft Nordwestdeutscher Geologen, 38. Tagung Holzminden 1971, Führer [guide] Exkurs. 4.6.1971: 1-3; Hannover.

Petit, J.R., Jouzel, J.D., Raynaud, D., Barkov, N. I., Barnola, J.-M., BAsile, I., Bender, M., Chappellaz, J., Davis, M., Delaygue, G., Delmotte, M., Kotlyakov, V. M., Legrand, M., Lipenkov, V.Y., Lorius, C., Pépin, L., Ritz, C., Saltzman, E. \& Stievenard, M. (1999): Climate and atmospheric history of the past 420,000 years from the Vostok ice core, Antarctica. - Nature, 399: 429-436. DOI:10.1038/20859.

Petit, J.R., Raynaud, D., Lorius, C., Jouzel, J., Delaygue, G., Barkov, N.I. \& KotLyAKov, V.M. (2000): Historical isotopic temperature record from the Vostok ice core. - In Trends: A compendium of data on global change. - Carbon Dioxide Information Analysis Center, Oak Ridge National Laboratory, U.S. Department of Energy. DOI:10.3334/CDIAC/ cli.006; Oak Ridge, TN, USA.

Reille, M., Beaulieu, J.-L. De., Svobodova, H., Andrieu-Ponel, V. \& Goeury, C. (2000): Pollen analytical biostratigraphy of the last five climatic cycles from a long continental sequence from the Velay region (Massif Central, France). - Journal of Quaternary Science, 15: 665-685.

Rohde, P. (1983): Geologische Karte von Niedersachsen 1:25 000, mit Erläuterungen [explanatory notes], sheet 3724 Pattensen. - 192 p., 43 fig., 31 tab., 2 pl., 8 maps; Hannover.

RoHde, P. (1986): Geo-Umwelt im Bergland-Quartär zwischen oberer Weser und Leine. - Deutsche Quartärvereinigung DEUQUA, 23. Tagung, Celle, Führer [guide] Exkurs. B: 45 p. + amendments, 19 fig., 1 tab., 1 incl.; Hannover.

RoHDE, P. (1989): Elf pleistozäne Sand-Kies-Terrassen der Weser: Erläuterung eines Gliederungsschemas für das obere Wesertal. - Eiszeitalter und Gegenwart, 39: 42-65, 4 fig., 2 tab.

Rohde, P. (1994): Weser und Leine am Berglandrand zur Ober- und Mittelterrassen-Zeit. - Eiszeitalter und Gegenwart, 44: 106-113, 2 fig..

Rohde, P. (2002):Geologische Karte von Niedersachsen 1: 25 000, mit Erläuterungen [explanatory notes], sheet 3519 Uchte Süd. - 208 p., 40 fig., 15 tab., 7 maps; Hannover. 
Rohde, P. (2008): Tongrube Nachtigall am SW-Rand der Subrosionssenke bei Albaxen - Stratigraphie und Schichtlagerung. - 2 maps (boundaries, contour lines), 3 vert. Sect.; Hannover. - [unpubl. - Landesamt für Bergbau, Energie und Geologie, archives: X 00282]

Rohde, P. \& Becker-Platen, J.D. (coord.) (1998): Geologische Stadtkarte Hannover $1: 25$ 000, Erläuterungen [explanatory notes]. - 156 p., 37 fig., 3 tab.; Niedersächsisches Landesamt für Bodenforschung, Hannover.

Rohde, P. \& Thiem, W. (1998): Die eiszeitliche Weser im heutigen Weserund Leine-Tal. - Quartär in Niedersachsen. DEUQUA-Exkurs.-Führer [excursion guide ]: 89-153, 20 fig., 7 tab.; Hannover.

Schlegel, F. (ed.) (1997): Werner von Heesen und die Albaxen-Chronik. 184 p.; Bochum (Verlag Bochumer Antiquariat).

Schreve, D.C. (ed.) (2004): The Quaternary mammals in southern and eastern England. Field guide. - VII + 128 p.; London.

SiegerT, L. (1913): Über die Entwicklung des Wesertales. - Zeitschrift der Deutschen Geologischen Gesellschaft, 64: 233-264.

Siegert, L. (1921): Beiträge zur Kenntnis des Pliocäns und der diluvialen Terrassen im Flußgebiet der Weser. - Abhandlungen der Preußischen Geologischen Landesanstalt, Neue Folge, 90: 130 p..

SoErgeL, W. (1927): Zur Talentwicklung des Weser-Werra- und des Ilm-Systems. - Geologische Rundschau, 18: 103-120.

Soergel, W. (1939): Das diluviale System. - Fortschritte der Geologie und Paläontologie,12 (39): 155-292.

STOLLER, J. (1928): Paläobotanische Untersuchungen von Interglazialtorfproben aus der Zeche Nachtigall. - 3 p.; Hannover. - [unpubl. - Landesamt für Bergbau, Energie und Geologie, archives: 0066220.]

StraAten, L. VAN (1982): Hydrogeologische Untersuchungen im Raum nördlich Höxter. - Dipl.-Arbeit Geol. Inst. Universität Hannover: 110 p., 3 append.; Hannover. - [unpubl. - Landesamt für Bergbau, Energie und Geologie, archives: 2007 B 1415]
Thiem, W. (1988): Das Oberwesertal im Raume Polle - Bodenwerder Hehlen. $\mathrm{Zu}$ aktuellen Problemen der Talgeschichte der Oberweser im Quartär. - Jahrbuch der Geographischen Gesellschaft zu Hannover, special 14: 273-326, 1 fig., 8 tab..

Tноме, K.N. (1998): Einführung in das Quartär. Das Zeitalter der Gletscher. - 287 p., 205 fig., 22 tab., 1 pl.; Berlin (Springer).

Tzedakis, P.C., Andrieu, V., Beaulieu, J.-L. de, Crowhurst, S. De, Follieri, M., Hooghiemstra, H., Magri, D., Reille, M., Sadori, L., Shackleton, N.J. \& Wijmstra, T.A. (1997): Comparison of terrestria and marine records of changing climate of the last 500,000 years. Earth and Planetary Science Letters 150: 171-176.

WaAs, D., Kleinmann, A. \& Lepper, J. (2011): Uranium-series dating of fen peat horizons from pit Nachtigall in northern Germany. - Quaternary International 241 (2011): 111-124: 14 p., 10 fig., 1 tab.. DOI: 10.1016/j. quaint.2010.09.010.

Winsemann, J., Brandes, C., Polom, U. \& Weber, C. (2011): Depositional architecture and palaeogeographic significance of Middle Pleistocene glaciolacustrine ice marginal deposits in northwestern Germany: a synoptic overview. - E\&G Quaternary Science Journal, 60, 2-3: 215235, 16 fig.. DOI 10.3285/eg.60.2-3.01.

Winsemann, J., Hornung, J.J., Meinsen, J., Asprion, U., Polom, U., Brandes, C., Bussmann, M. \& Weber, C. (2009): Anatomy of a subaqueous ice-contact fan and delta complex, Middle Pleistocene, NW Germany. - Sedimentology, 56: 1041-1076.

Wortmann, H. (1968): Die morphogenetische Gliederung der Quartärbasis des Wiehengebirgsvorlandes in Nordwestdeutschland. - Eiszeitalter und Gegenwart, 19: 227-239, 4 fig., 1 tab., 1 pl.

Wortmann, H. ¿ Wortmann, A. (1987):Glaziäre Ablagerungen und Terrassengliederung der Weser im Raum zwischen Eisbergen und Porta Westfalica (Nordwestdeutschland). - Eiszeitalter und Gegenwart 37: 93-98. 